\title{
Verification of Test Conditions to Determine the Compression Modulus of Elasticity of Wood
}

\author{
Fabiane Salles Ferro ${ }^{1}$, FelipeHideyoshi Icimoto $^{1}$, Diogo Henrique de Almeida ${ }^{2}$, André Luis Chris toforo ${ }^{3, *}$, \\ Francis co Antonio Rocco Lahr'
}

\begin{abstract}
${ }^{1}$ Department of Science and En gineering Material, Engineering School of São Carlos (EESC/USP), São Carlos, 13566-590, Brazil
${ }^{2}$ Department of Structural Engineering, En gin eering School of São Carlos (EESC/USP), São Carlos, 13566-590, Brazil

${ }^{3}$ Department of Mechanical En gin eering, Federal Univ ersity of São João del-Rei, São João del-Rei, 36307-352, Brazil
\end{abstract}

\begin{abstract}
The obtaining the modulus of elasticity in compression of the wood with the use of dial gauges, fixed on opposite faces of the specimens, may lead to deformation values and consequently to different elastic modulus as a function of the faces chosen for its attachment, being the timber an anisotropic material. This study aimed to evaluate the influence of two distinct positions for setting the dial gauges (A and B) in wood specimens tested in compression, using the assumptions of the test methods and calculation of the Brazilian standard ABNT NBR 7190: 1997. The woods evaluated in trials were the Pinus elliottii and Corymbia citriodora, being used seven specimens per species. A specimen was taken to the rupture, obtained the values of the maximum stress and strain (references) needed to obtain the elastic moduli of the six remaining specimens per species, certain non-destructively (two tests per piece). The results of analysis of variance revealed the equivalence between modules elasticity in compression parallel to the grain for both wood species investigated, resulting not significantly arrangement of dial gaugesto determine the properties of stiffness. However, the anisotropy of wood, these results cannot be extrapolated to other woods of the same or different species, justifying the setting of dial gauges in two different positions, allowing for judging whether or not the equivalence between the modulus of elasticity.
\end{abstract}

Keywords Wood, Compression Parallel to the Grain, Stiffness

\section{Introduction}

The wood itself as one of the oldest building materials, being used mainly because of its availability in nature, ease of handling, manufacturing and excellent relationship weight/strength[1-3].

The timber was presented as a cellular material, produced by a mechanism of continuous growth of plants. There are several species of trees throughout the world, but with all common features such as a cellular structure with an arrangement in the form of concentric rings, which ensures orthotropic mechanical properties of wood, directly related to its orientation relative to the main axis [4].

Chemical and mechanical properties can differ for the same species of wood according to the location of their extraction. Other parameters such as climate and soil conditions can affect the growth of the tree, directly influencingtheir properties. Moreover, factors such as the presence of us, opening cracks during drying and inclination of the fibers cause the strength of the woods have great

* Corresponding author:

alchristo foro@y ahoo.com.br (André Luis Christoforo)

Published online at http://journal.sapub.org/ijaf

Copyright (C) 2013 Scientific \& Academic Publishing. All Rights Reserved variations [5-7].

According to[1], the mechanical properties of wood are dependent on the density, the percentage of juvenile wood, the width of the rings, the angle of the microfibrils, the amount of extractives, moisture content, the intensity of insect attack, the type and location and number of nodes, among other factors, making it difficult to obtain need all their elastic parameters to be used in structural projects $[8,9]$.

In order to enable the rational use of wood in structures mechanical tests are performed to obtain the equivalent properties, obtained from experiments and calculation procedures of standardized normative documents, such as the standard ABNT 7190[10], widely used by engineers, architects and designers for material characterization due to mechanical stresses and also for proper and safe design of structural elements.

Among the mechanical properties of materials used in the design of a structure highlights the modulus of elasticity (MOE), enabling the setting to provide displaced and deformations in structural components subjected to the action of the imposed loads (limit state).

Be of great interest for the knowledge of the modulus of elasticity in compression wood, allowing the design of structural elements subject to compressive stresses, several studies have been conducted[11-19], in order to verify 
experimentally and numerically the influence of composition anatomical tissue timber (anisotropy) in physical, chemical and mechanical properties, as well as to characterize wood species not yet known.

This study aimed to investigate the influence of positioning of dial gauges (positions A and B) to determine the modulus of elasticity of wood in compression parallel to the grain, enabling determine possible differences between then.

\section{Materials and Methods}

The wood species used in this study were the Corymbia citriodora (Strength class C40) and Pinus elliottii (Strength class C30), made seven specimens per type of timber to perform in compression test[10], extracted from different parts of a batch considered homogeneous, with mo isture content near $12 \%$, as established by the Brazilian standard[10].

The specimens were manufactured with square cross section of $5.0 \mathrm{~cm}$ and $15 \mathrm{~cm}$ of length[10], and are free of defects. The dimensions of the sides of the specimens were performed with a caliper accurate to $0.1 \mathrm{~mm}$.

The dial gaugeswere fixed in two different positions, A and B, as illustrated in Figure 1, two bending tests were performed in the same specimen perwood species. Of each species, one of seven specimens was taken to rupture, allowing discover tensions $(\sigma)$ and strain $(\varepsilon)$ for the $10 \%$ and $50 \%$ of the maximumstresses and strains, used to determine the modulus of elasticity (Equation 1) in the other specimens, as required by the Brazilian standard[10].

$$
E_{c, 0}=\frac{\sigma_{50 \%}-\sigma_{10 \%}}{\varepsilon_{50 \%}-\varepsilon_{10 \%}}
$$

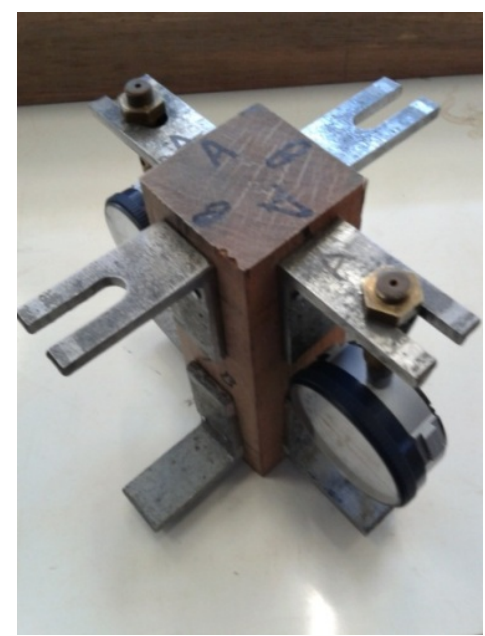

Figu re 1. Specimen timber with Corymbia citriodora setting the dial indicators: Positions A and B

To check the statistical equivalence between the modulus of elasticity for the two species of wood was used analysis of variance (ANOVA), performed as an aid software Minitab ${ }^{\circledR}$ version 14 .

\section{Results}

Tables 1 and 2 present the descriptive statistics related to the modulus of elasticity (MOE-A,-B MOE) in compression parallel to the grain ofCorymbia citriodora and Pinus elliottiiwood respectively, obtained with the use of dial gauges positioned on the faces A and B (Figure 1), $X_{m}$ is the arithmetic mean, $\mathrm{SD}$ the standard deviation and $\mathrm{CV}$ the variation coefficient of specimens.

Table 1. Modulus of elasticity of Corymbia citriodora wood

\begin{tabular}{ccc}
\hline Specimen & MOE-A (MPa) & MOE-B (MPa) \\
\hline 1 & 15545 & 17458 \\
2 & 21736 & 11960 \\
3 & 16764 & 16641 \\
4 & 24706 & 19352 \\
5 & 17310 & 18189 \\
6 & 17629 & 15470 \\
\hline$X_{m}$ & 18948 & 16512 \\
$D P$ & 3512,9 & 2592,1 \\
$C V(\%)$ & 19 & 16 \\
\hline
\end{tabular}

Table 2. Modulus of elasticity of Pinus elliottii wood

\begin{tabular}{ccc}
\hline Specimen & MOE-A (MPa) & MOE-B (MPa) \\
\hline 1 & 8697 & 7913 \\
2 & 10062 & 10409 \\
3 & 12963 & 10985 \\
4 & 9119 & 11038 \\
5 & 13634 & 14636 \\
6 & 10343 & 8683 \\
\hline$X_{m}$ & 10803 & 10611 \\
$D P$ & 2035,3 & 2347,8 \\
$C V(\%)$ & 20 & 22 \\
\hline
\end{tabular}

Figure 2 shows the normality graphs of the modulus of elasticity ofCorymbia citriodora and Pinus elliottiiwood respectively.

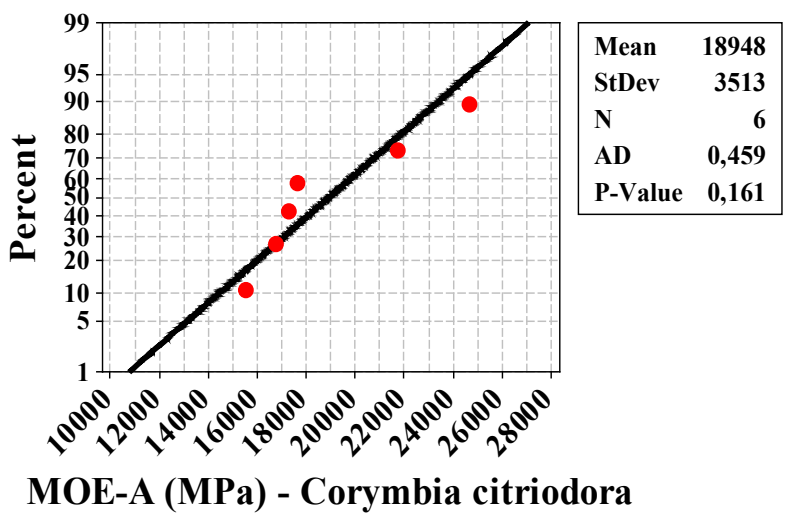

(a) 


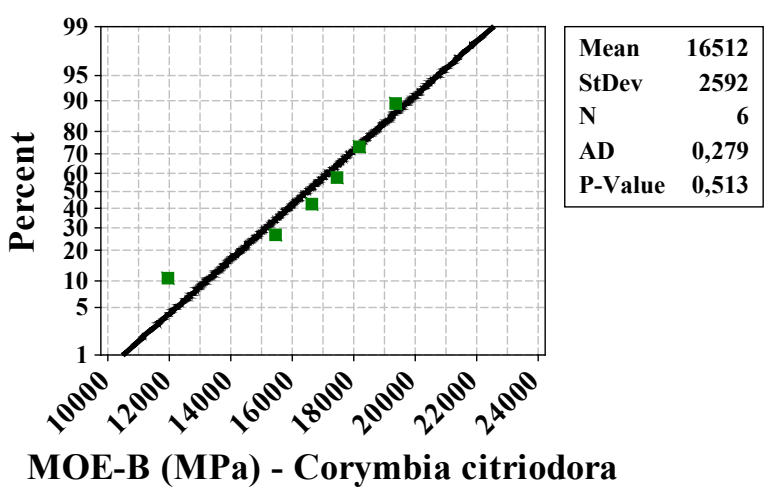

(b)

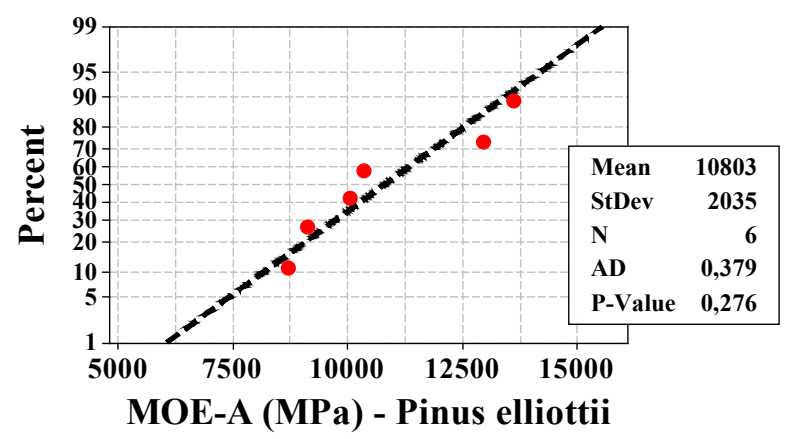

(c)

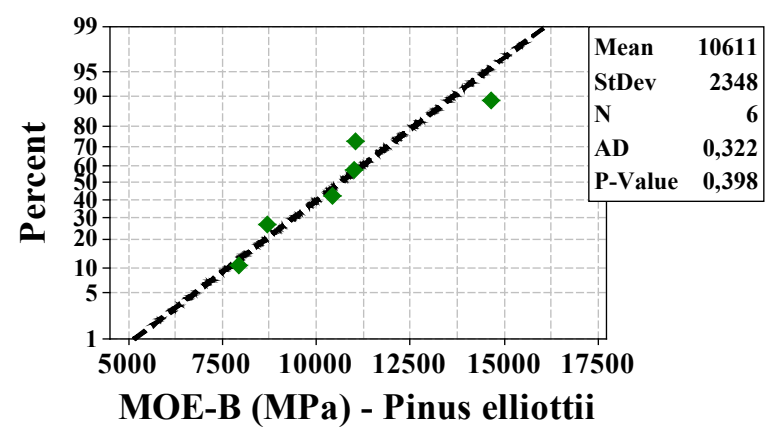

(d)

Figure 2. Graphs of normality for the modulus of elasticity of the woods investigated

The P-values of normality tests of Anderson-Darling (Figure 2) on the modulus of elasticity for the Corymbia citriodora (0.161) and Pinus elliottii (0.513) woods were both higher than 0.05 , proving to be normal the data distribution[21].

Table 3 shows the results of the ANOVA factor, position of the dial gauge to obtain the modulus of elasticity (MOE-A; EOM B).

Table 3. P-values from the ANOVA on the MOE of the wood investigated

\begin{tabular}{ccc}
\cline { 3 - 3 } & P-valor & $\mathbf{R}^{\mathbf{2}}$ (Adj.) \\
Corymbia citriodora & 0,202 & $7,32 \%$ \\
Pinus elliottii & 0,882 & $0,00 \%$ \\
\hline
\end{tabular}

Figure 3 shows the main effect plots of the MOE for the wood species evaluated.

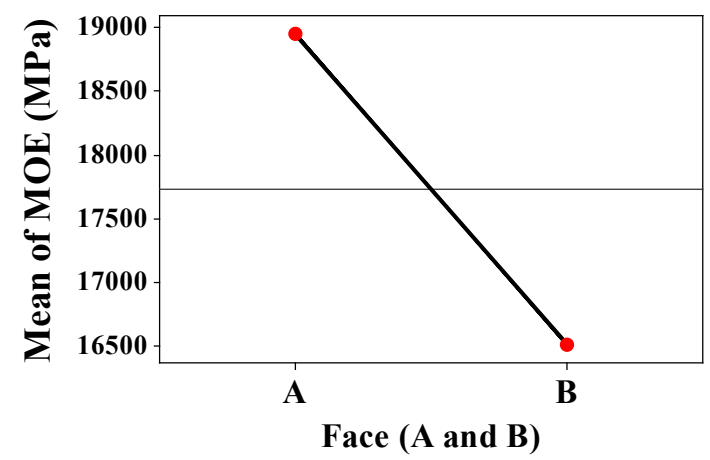

(a)

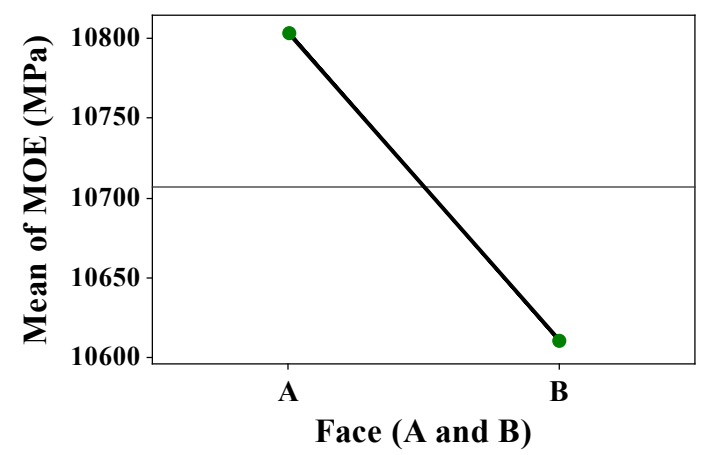

(b)

Figure 3. Main effects plot of the MOE for the Corymbia citriodora (a) and Pinus elliottii (b) wood species

P-values obtained by ANOVA of MOE for both wood species were greater than $0.05[21]$, notes the equivalence between the values, there was no significant the position of the dial gauges to determine the stiffness properties of wood evaluated.

To validate the results of the ANOVA, it is necessary to ensure normality, independence and homogeneity of the residuals for the MOE of both wood species. Figures 4 and 5 shows the results concerning the normality of the residuals for the rig idity of both wood species, and independence and uniformity shown in Figures 6 and 7.

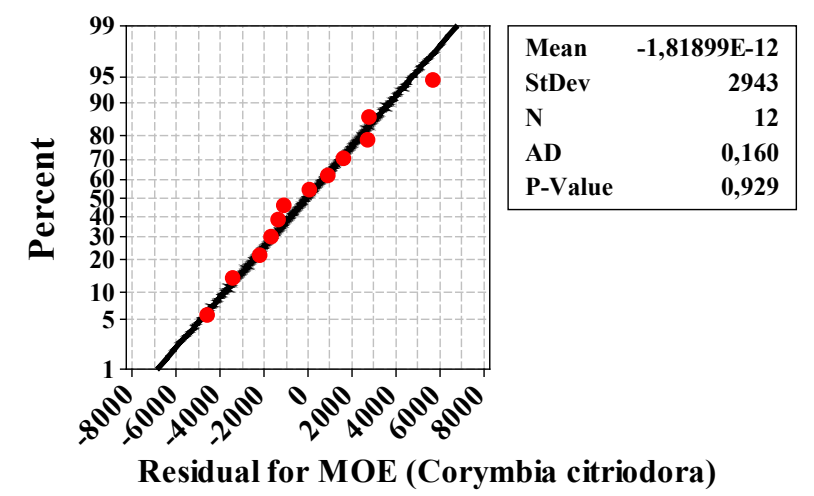

Figure 4. Normality plot of residuals of ANOVA on MOE for the Corymbia citriodora species 


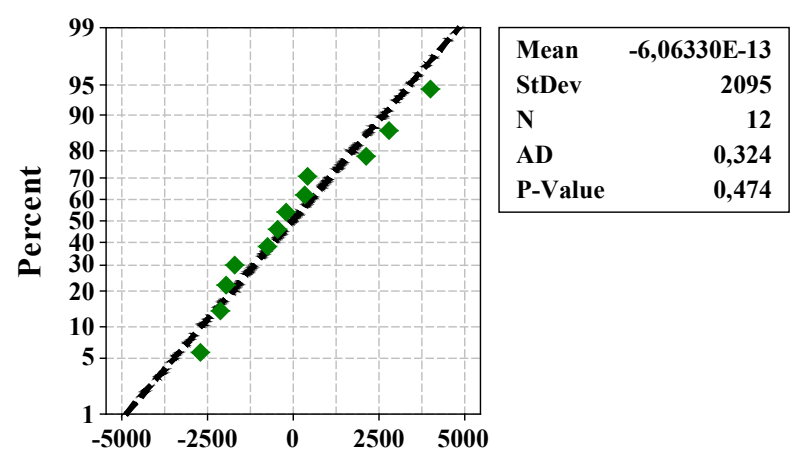

Residual for MOE (Pinus elliottii)

Figure 5. Normality plot of residuals of ANOVA on MOE for the Pinus elliottii wood species

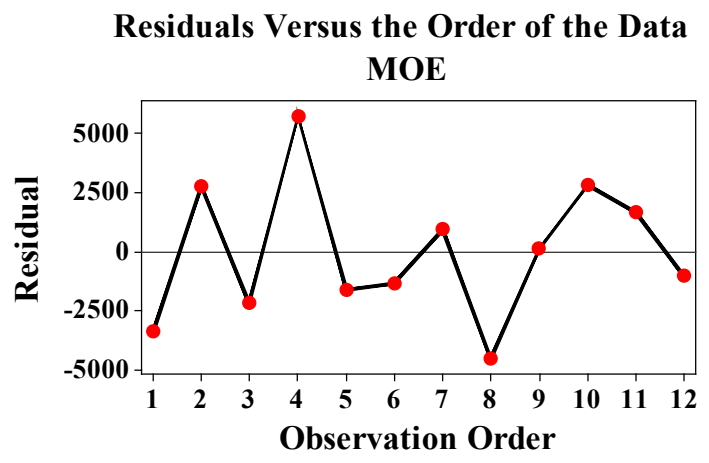

(a)

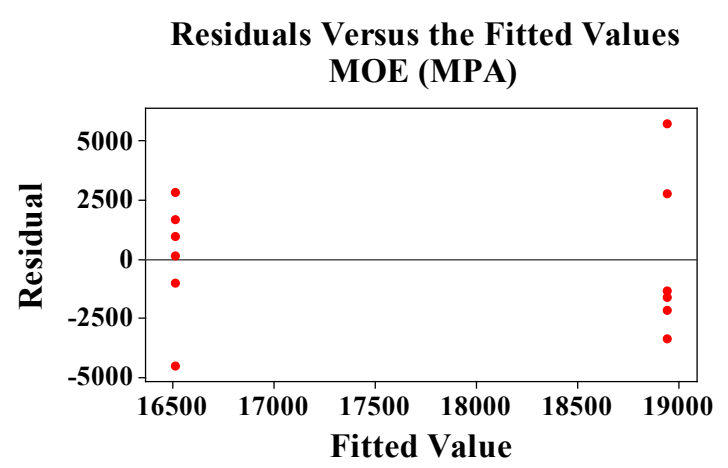

(b)

Figure 6. Independence (a) homogeneous and (b) residuals of ANOVA on the MOE of wood Corymbia citriodora wood species

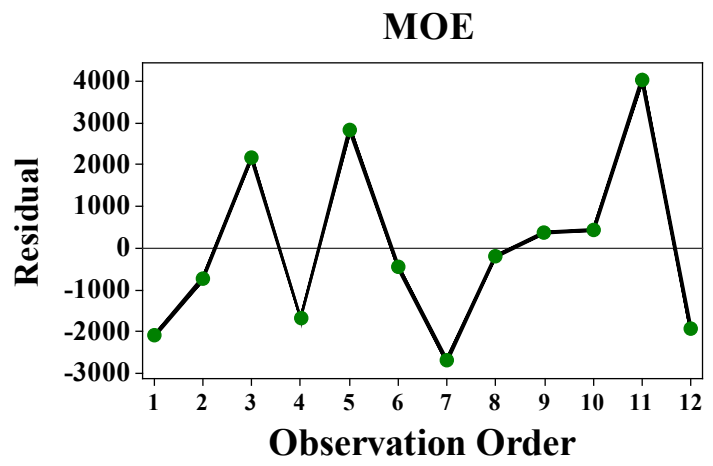

(a)

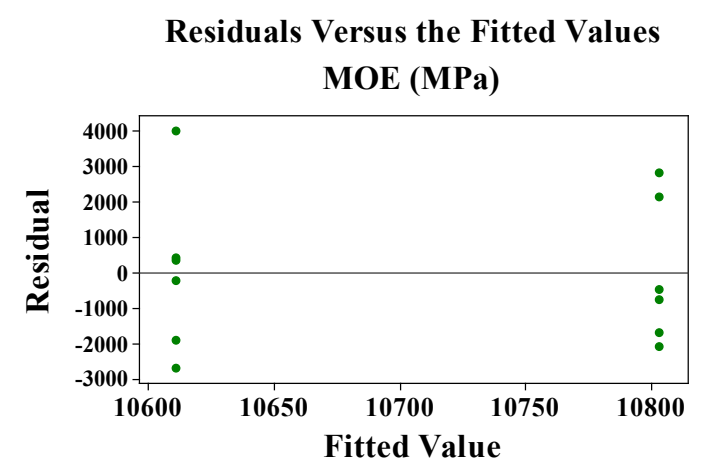

(b)

Figure 7. Independence (a) homogeneous and (b) residuals of ANOVA on the MOE of Pinus elliottii wood species

The results shown by the graphs of Figures 2-7 validate the ANOVA model, proving they are the equivalent the compression modulus of elasticity of the wood investigated.

\section{Conclusions}

By the results of the analysis of variance was verified statistical equivalence between the modulus of elasticity of both wood species, revealing, for the specimens tested, not significant position of dial gauges in the calculation of the modulus of elasticity. As the wood an anisotropic material (orthotropic), the results obtained in this study cannot be extrapolated to the same wood species or different species, imply ing the use of dial gauges in two different positions in the specimen, enabling assess equivalence or not of the elastic moduli obtained.

\section{REFERENCES}

[1] Calil, C. Jr.; Lahr, F. A. R.; Dias, A. A. Dimensionamento de elementos estruturais de madeira. Barueri - SP: Manole Ltda, ISBN: 85-204-1515-6, 2003.

[2] Zangiácomo, A. L. Estudo de elementos estruturais roliços de madeira. Tese (Doutorado). Engenharia Civil, Departamento de Engenharia de Estruturas. Escola de Engenharia de São Carlos doa Universidade de São Carlos (EEESC/USP). São Carlos (SP), 2007.

[3] Christoforo, A. L.; Rocco, F. A. L.; Morales, E. A. M.; Zangiácomo, A. L.; Panzera, T. H. Influence of Displacements on Calculus of the Longitudinal Modulus of Elasticity of Pinus Caribaea Structural Round Timber Beams. International Journal of Agriculture and Forestry, v. 2, p. 157-160, 2012.

[4] Balseiro, A.; Negrão, J.; Faria, J. A. Reforço de vigas de madeira com laminados de carbono pré-esforçados. Construlink.com - Tecnologias de Informação, S.A., n. 16, v. 6., p. 14-24, ISSN 1645-5576, Lisboa (PT), 2008.

[5] Christoforo, A. L. Influência das irregularidades da forma em peças de madeira na determin ação do módulo de elasticidade longitudinal. Tese de Doutorado. Escola de Engenharia de 
São Carlos da Universidade de São Paulo EESC/USP, São Carlos (SP), 2007.

[6] Christoforo, A. L.; Panzera, T. H.; Batista, F. B.; Borges, P. H.; Rocco, F. A. L.; Franco, C. F. The position effect of structural Eucalyptus round timber on the flexural modulus of elasticity. Revista Engenharia Agrícola, v. 31, p. 1219-1225, 2011.

[7] Rocco Lahr, F. A. R. Sobre a determin ação de propriedades de elasticidade da madeira. 216p. Tese de Doutorado. Escola de Engenharia de São Carlos, Universidade de São Paulo, São Carlos - SP, 1983.

[8] Christoforo, A. L.; Romanholo, G. A.; Panzera, T. H.; Borges, P. H.; Rocco, F. A. L. Influence of stiffness in bolted connections in wooden plane structure of truss type. Revista Engenharia Agrícola, v. 31, p. 998-1006, 2011.

[9] Christoforo, A. L.; Rocco, F. A. L.; Morales, E. A. M.; Zangiácomo, A. L.; Panzera, T. H. Influence of Displacements on Calculus of the Longitudinal Modulus of Elasticity of Pinus Caribaea Structural Round Timber Beams. International Journal of Agriculture and Forestry, v. 2, p. 157-160, 2012.

[10] Associação Brasileira de Normas Técnicas (ABNT): NBR7190. Projeto de estruturas de madeira. Rio de Janeiro, 1997.

[11] Rocco Lahr, F. A., Robles, D. G. Characterization of alternative species of wood for employment in civil construction. In: Proceedings of the 2th International Symposium on Natural Polymers and Composites; Atibaia (Brasil), p.115-120, 1998.

[12] Rocco Lahr, F. A.; Dias A. A. Maderas tropicales brasileñas alternativas. Madera: Ciencia y Tecnologia, v.1, p. 7-14, 1999.
[13] Gong, M.; Smith, I. Failure of softwood under static compression parallel to grain. Journal of the Institute of Wood Science, v 15, n 4, p. 204-210, 2000.

[14] Gindl, W. Comparing mechanical properties of normal and compression wood in Norway spruce: The role of lign in in compression parallel to the grain Holzforschung, v. 56, n. 4, p. 395-401, 2002.

[15] Xavier J, Avril S, Pierron F, Morais J. Novel experimental approach for longitudinal-radial stiffness characterisation of clear wood by a single test. Holzforschung; v.61, p. 573-81, 2007.

[16] Benabou, L. Kink band formation in wood species under compressive loading. Society for Experimental Mechanics, Inc., v. 65, p. 647-656, 2008.

[17] Gryc, V.; Vavrcík, H. Variability of spruce (Picea abies[L.] Karst.) compression strength with present reaction wood. Journal of Forest Science, v. 55, n. 9, p. 415-422, 2009.

[18] Silva, D. A. L. Rocco Lahr, F. A.; De Faria, O. B.; Chahud, E. Influence of wood moisture content on the modulus of elasticity in compression parallel to the grain Materials Research, v. 15, n. 2, p. 300-304, 2012.

[19] Xavier, J; Jesus, A. M. P.; Morais, J. J. L.; Pinto; J. M. T. Stereovision measurements on evaluating the modulus of elasticity of wood by compression tests parallel to the grain. Construction and Building Materials, v. 26, p. 207-215, 2012.

[20] Ferro, F. S.; Icimoto, F. H.; Almeida, D. H.; Rocco Lahr, F. A. Influência das condições de ensaio nos valores do módulo de elasticidade da madeira na compressão paralela às fibras. In: XX Congresso Brasileiro de Engenharia e Ciência dos Materiais, 2012, Joinville, SC. Anais do XX CBECIMAT, 2012. v. único. p.5354-5361.

[21] Montgomery, D. C. Design and analy sis of experiments. John Wiley \& Sons Inc., 6 ${ }^{\text {a }}$ edition, Arizona, 2005. 